\title{
Agnieszka Serlikowska
}

orcid: 0000-0002-1363-8906

\section{Z prawnej problematyki finansowania urzędowej kontroli żywności}

\section{Wstęp}

Opłaty za przeprowadzenie kontroli uważane są za element modelowy urzędowej kontroli żywności ${ }^{1}$. Wskazuje się, że określenie ram tych opłat na poziomie unijnym przyczynia się do zapewnienia swobodnego przepływu towarów oraz gwarantuje równe warunki konkurencji dla podmiotów prowadzących działalność w poszczególnych państwach członkowskich ${ }^{2}$. Jednak w istocie opłaty te są tylko jednym z zagadnień objętych regulacją dotyczącą finansowania kontroli urzędowych określoną w rozdziale VI rozporządzenia nr 882/2004², a już wkrótce zastępującego go rozporządzenia nr 2017/6254.

1 Dalej również jako: ukż.

${ }^{2}$ Zob. P. Wojciechowski, Wspólnotowy model urzędowej kontroli żywności, Warszawa 2008, s. 313.

${ }^{3}$ Rozporządzenie (WE) nr 882/2004 Parlamentu Europejskiego i Rady z dnia 29 kwietnia 2004 r. w sprawie kontroli urzędowych przeprowadzanych w celu sprawdzenia zgodności z prawem paszowym i żywnościowym oraz regułami dotyczącymi zdrowia zwierząt i dobrostanu zwierząt (Dz.Urz. UE L 165 z 30 kwietnia 2004 r., s. 1 ze zm.), dalej jako: rozporządzenie nr 882/2004. Rozporządzenie to zostanie uchylone $\mathrm{z}$ dniem 13 grudnia $2019 \mathrm{r}$.

${ }^{4}$ Rozporządzenie Parlamentu Europejskiego i Rady (UE) nr 2017/625 z dnia 15 marca 2017 r. w sprawie kontroli urzędowych i innych czynności urzędowych przeprowadzanych w celu zapewnienia stosowania prawa żywnościowego i paszowego oraz zasad dotyczących zdrowia i dobrostanu zwierząt, zdrowia roślin i środków ochrony roślin, zmieniające rozporządzenia Parlamentu Europejskiego i Rady (WE) nr 999/2001, (WE) nr 396/2005, (WE) nr 1069/2009, (WE) nr 1107/2009, (UE) nr 1151/2012, (UE) nr 652/2014, (UE) 2016/429 i (UE) 2016/2031, rozporządzenia Rady (WE) nr 1/2005 i (WE) nr 1099/2009 oraz dyrektywy Rady 98/58/WE, 1999/74/WE, 2007/43/WE, 2008/119/WE i 2008/120/WE, oraz uchylające rozporządzenia Parlamentu Europejskiego i Rady (WE) nr 854/2004 i (WE) nr 882/2004, dyrektywy Rady 89/608/EWG, 89/662/EWG, 90/425/EWG, 
Według przytoczonych aktów prawnych do obowiązków państw członkowskich należy zapewnienie dostępności środków finansowych przeznaczonych na organizowanie kontroli urzędowych, w szczególności poprzez możliwość nakładania opłat i należności w celu pokrycia kosztów poniesionych w ramach tych kontroli ${ }^{5}$. Prawodawca unijny uznał, że gwarantem sprawnego funkcjonowania urzędowej kontroli żywności jest jej odpowiednie finansowanie. Prawna problematyka tego zagadnienia dotyczy przede wszystkim zastosowanych przez prawodawcę instytucji prawnych oraz prawnych konsekwencji przyjętych rozwiązań.

Za podjęciem tematyki określonej w tytule artykułu przemawiają względy teoretyczne i praktyczne. Gdy chodzi o te pierwsze, podkreślić należy pomijanie aspektu finansowego przy analizowaniu problematyki urzędowej kontroli żywności. Choć instynktownie chciałoby się te zagadnienia pozostawić doktrynie prawa finansowego, nie sposób nie zauważyć, że wpływają one w sposób istotny na sytuację podmiotów prowadzących przedsiębiorstwa spożywcze i działających na rynku pasz, a także na efektywność i skuteczność samej ukż. Ponadto z uwagi na ich ścisłe powiązanie z prawem żywnościowym, również doktryna prawa finansowego pozostawia je na uboczu swoich badań. W rezultacie problematyka ta stała się swego rodzaju ziemią niczyją, nieomawianą przez zajmujących się ani jedną, ani drugą gałęzią.

Z perspektywy praktyki analiza podstawowych zagadnień dotyczących finansowania urzędowej kontroli żywności może być przydatna na etapie administracyjnego i sądowego stosowania prawa. Pomocna może okazać się również w procesie tworzenia prawa. W szczególności z uwagi na fakt, że część norm dotyczy ustanawiania przez państwa członkowskie należności na rzecz organów ukż oraz dotyka problematyki pozafinansowych wpływów, jakie należności te mają wywrzeć na podmiotach nimi obciążanych.

Biorąc pod uwagę powyższe, celem artykułu jest próba oceny ustanowionych przez prawodawcę unijnego instrumentów prawnych dotyczących finansowania urzędowej kontroli żywności pod kątem zapewnienia przez te instrumenty jej właściwego funkcjonowania, zarówno z perspektywy regulacji krajowych, jak i praktyki.

91/496/EWG, 96/23/WE, 96/93/WE i 97/78/WE oraz decyzję Rady 92/438/EWG (rozporządzenie w sprawie kontroli urzędowych) (Dz. Urz. UE L 95 z 7 kwietnia 2017 r., s.1 ze zm.), dalej jako rozporządzenie nr 2017/625. Rozporządzenie to zacznie być stosowane z dniem 14 grudnia $2019 \mathrm{r}$.

${ }_{5}^{5}$ Por. motyw 32 preambuły i art. 26 rozporządzenia nr 882/2004, motyw 65 preambuły i art. 78 rozporządzenia nr 2017/625. 


\section{Finansowanie urzędowej kontroli żywności - uwagi ogólne}

Rozdział VI rozporządzenia nr 882/2004, zatytułowany „finansowanie kontroli urzędowych", zawiera jedynie cztery lakoniczne artykuły. Z treści motywu 32 preambuły oraz art. 26 rozporządzenia nr 882/2004, wynika, że - z dość oczywistych względów - prawodawca postrzega środki finansowe jako gwarancję prawidłowego funkcjonowania urzędowej kontroli żywności. Omawiane przepisy mają zatem na celu ustanowienie instrumentów zapewniających systemowi kontroli urzędowych względną stabilność finansową.

Prawodawca unijny pozostawił swobodę państwom członkowskim w postaci wyboru instytucji gwarantujących tę stabilność. Katalog w tym zakresie jest otwarty, ponieważ ogólne opodatkowanie i ustanowienie opłat lub należności wymienione zostały w art. 26 jedynie jako jeden ze sposobów realizacji ww. gwarancji ${ }^{6}$.

W rozporządzeniu nr 2017/625, które zacznie obowiązywać już od 14 grudnia 2019 r., wzrosła waga zapewnienia urzędowej kontroli żywności stabilności finansowej, a opłaty i należności zyskały rangę podstawowego instrumentu zmierzającego do jej osiągnięcia. W motywie 65 preambuły zostało wskazane, że właściwe organy powinny pobierać opłaty lub należności na pokrycie ponoszonych przez nie kosztów przy przeprowadzaniu kontroli urzędowych, aby ograniczyć zależność systemu kontroli urzędowych od finansów publicznych. Oczywiście, preambuła aktu unijnego nie ma mocy wiążącej ${ }^{7}$, niemniej jednak można wyczytać z niej intencję prawodawcy. Jak zatem rozumieć tę chęć ograniczenia zależności ukż od finansów publicznych?

Zauważyć należy, że nie chodzi tu o całkowite oderwanie się urzędowej kontroli żywności od władzy publicznej danego państwa członkowskiego. Prawodawca wskazuje przecież wyraźnie na obowiązki poszczególnych organów administracji publicznej w tym zakresie ${ }^{8}$. Co więcej, we wspomnianym motywie preambuły sam wskazuje na konieczność istnienia systemu kontroli urzędowych utrzymywanym przez każde państwo członkowskie w celu zapewnienia skutecznego nadzoru rynku w całym łańcuchu rolno-spożywczym.

Wydaje się, że kluczem do zrozumienia intencji prawodawcy jest pojawiający się w przepisach dotyczących finansowania ukż cel pokrycia jej kosztów oraz opisywana potrzeba zachowania stałego dostępu organów ukż do środków

${ }^{6}$ Obowiązkowy tylko w zakresie określonym w art. 27 ust. 2 rozporządzenia nr 882/2004.

7 Zob. np. wyrok Trybunału Sprawiedliwości, dalej również jako: TS z 2 kwietnia 2009 r. w sprawie C-134/08 Hauptzollamt Bremen przeciwko J.E. Tyson Parketthandel, GmbH hanse j, ECLI:EU:C:2009:229.

${ }^{8}$ Por. art. 3 pkt 3 lit. a i pkt 4 oraz art. 4 rozporządzenia nr 2017/625. 
finansowych tak, by kontrole mające na celu zapewnienie przestrzegania przepisów prawa żywnościowego nie ustały na przykład pod koniec roku z uwagi na deficyt w budżecie danego państwa członkowskiego.

Prawodawca unijny uznał, że metodą na pełne pokrycie kosztów urzędowej kontroli żywności będzie nieinkorporowanie pobranych z tytułu należności kwot do budżetów państwa i bezpośrednia możliwość gospodarowania nimi przez organy ukż - w domyśle z przeznaczeniem na kolejne kontrole i inne czynności. Zamysłem jest zatem stworzenie swego rodzaju finansowego łańcucha pozwalającego na stałą aktywność organów ukż w zakresie weryfikacji przestrzegania unijnego prawa żywnościowego. Można pokusić się o stwierdzenie, że intencją prawodawcy jest częściowa odrębność organów ukż od budżetu państwa. Swego rodzaju quasi-autonomia pozwalająca na stałą kontrolę respektowania przepisów prawa żywnościowego powinna mieć jednak swoje ograniczenia i dopuszczać finansowanie również z budżetu państwa. Całkowite uniezależnienie systemu ukż od finansów publicznych jednocześnie uzależniłoby organy ukż od podmiotów kontrolowanych, ponieważ od ilości kontroli i przeprowadzonych innych czynności zależałaby płynność finansowa takich organów. Mogłoby to doprowadzić do wypaczeń systemu oraz zjawisk korupcjogennych? ${ }^{9}$.

\section{Instrumenty finansowania urzędowej kontroli żywności}

Według art. 26 rozporządzenia nr 882/2004 zapewnienie przez państwa członkowskie środków finansowych może zostać osiągnięte wszelkimi sposobami uznanymi za właściwe, w tym poprzez ogólne opodatkowanie lub poprzez ustanowienie opłat lub należności. Treść art. 27 ust. 10 sugeruje jednak, że w przypadku, gdy państwa członkowskie zdecydowały się na ustanowienie opłat lub należności, stają się one ograniczone treścią całego art. 27 i nie mogą pobierać innych opłat niż wskazane w tym przepisie. Ogólne opodatkowanie oraz inne niż opłaty i należności instrumenty, ustanowione przez państwa członkowskie na rzecz organów ukż, podlegają natomiast przede wszystkim regulacjom krajowym.

Do konstrukcji art. 26 i 27 rozporządzenia nr 882/2004 odniósł się Trybunał Sprawiedliwości w wyroku z 17 marca 2016 r. w sprawie C-112/15 ${ }^{10}$. Zwrócił

${ }^{9}$ Por. EFLA, Workshop on the revision of Regulation (EC) 882/2004 on official controls, 2015, Wiedeń.

${ }^{10}$ Wyrok Trybunału Sprawiedliwości z 17 marca 2016 r, C-112/15, Kødbranchens Fællesråd, działający w imieniu Århus Slagtehus A/S, Danish Crown A.m.b.A. Oksekødsdivisionen, Hadsund Kreaturslagteri A/S, Hjalmar Nielsens Eksportslagteri A/S, Kjellerup Eksportslagteri A/S, Mogens Nielsen Kreaturslagteri A/S, Vejle Eksportslagteri A/S, przeciwko Ministeriet for Fødevarer, Landbrug og Fiskeri, Fødevarestyrelsen, ECLI:EU:C:2016:185. 
uwagę, że art. 26 tego aktu przewiduje zarówno wykorzystanie ogólnego opodatkowania, jak i ustanowienie opłat lub należności w celu zagwarantowania niezbędnego personelu oraz innych środków na kontrole urzędowe. Art. 27 dotyczy natomiast wyłącznie opłat oraz należności i zezwala państwom członkowskim na ich pobieranie jedynie na ,pokrycie kosztów poniesionych w ramach kontroli urzędowych". TS uznał jednocześnie, że opłaty mogą być przeznaczone tylko na pokrycie kosztów obciążających państwa członkowskie i wynikających w rzeczywistości z prowadzenia kontroli w przedsiębiorstwach sektora spożywczego.

Powyższe ograniczenie nie sprawiło jednak, by w rozporządzeniu nr 882/2004 czy nr 2017/625 zdefiniowano pojęcie „opłaty” i „należności”. Kwestię tę pozostawiono prawodawstwu i judykaturze poszczególnych państw członkowskich. Wskazówką mogą być jednak różne wersje językowe unijnych rozporządzeń. Uwzględniając koncepcję racjonalnego prawodawcy, można przyjąć założenie, że użyte w powyższych aktach terminy są adekwatne do tych stosowanych $\mathrm{w}$ aktach prawnych związanych z prawem finansowym poszczególnych państw członkowskich.

Przykładowo - w języku angielskim „fees or charges” oraz polskim „opłaty lub należności" - oba pojęcia mają w istocie podobne znaczenie dotyczące finansowej rekompensaty za konkretne działania organów administracji publicznej, wykonywane w związku z ich obowiązkami określonymi prawem. Zauważyć jednak należy, że polskim prawie finansów publicznych opłata jest rodzajem należności ${ }^{11}$. W rezultacie jedno określenie z tej perspektywy wydaje się zbędne.

We francuskiej wersji językowej (,,redevances ou taxes”) - pierwszy z terminów odnosi się również do finansowej rekompensaty, natomiast drugi związany jest z podatkiem. W tym kontekście zastanawia jednak dwukrotne odwołanie się przez prawodawcę do koncepcji podatku. $Z$ dosłownego thumaczenia francuskiej wersji językowej art. 26 rozporządzenia nr 882/2004 wynikałoby, że zapewnienie odpowiednich środków finansowych ma odbywać się poprzez ogólne opodatkowanie lub poprzez ustanowienie opłat lub podatku.

Zaskakująca jest również zmiana nazewnictwa tych instrumentów w języku włoskim. W tej wersji językowej rozporządzenia nr 882/2004 nazwy użytych instrumentów prawnych zastosowano podobnie, jak w wersji francuskiej (,tasse o diritti”), czyli w istocie byłaby to opłata i podatek. Jednak w rozporządzeniu nr 2017/625 pojęcia te ukształtowano podobnie do wersji angielskiej czy polskiej („t a r i ffe o diritti”). Tym samym prawodawca europejski wyeliminował

${ }^{11}$ Por. wyrok WSA we Wrocławiu z dnia 28 czerwca 2011 r., sygn. akt II SA/Wr 838/11, wyrok WSA w Lublinie z dnia 26 stycznia 2012 r., sygn. akt II SA/Lu 822/11 oraz wyrok WSA w Warszawie z dnia 27 marca 2006 r., sygn. akt IV SA/Wa 1616/05 na tle opłat z art. 30 ust. 1 ustawy o Inspekcji Weterynaryjnej, art. 3 pkt 8 ustawy z dnia 29 sierpnia 1997 r. Ordynacja podatkowa (t.j. Dz.U. z 2018 r., poz. 800 ze zm.). 
potencjalną wątpliwość w tym zakresie w języku włoskim, zachowując jednocześnie stare nazewnictwo dla wersji francuskiej. Oczywiście można uznać, że to jedynie kwestia leksykalna. Jednak nie zmienia to faktu, że poszczególne wersje językowe są wskazówką do wykładni aktów unijnych. Zauważyć należy ponadto, że prawodawca unijny już raz optował za całkowitym wyeliminowaniem generalnego opodatkowania jako sposobu na finansowanie $u k \dot{z}^{12}$.

\section{Inne instrumenty finansowania urzędowej kontroli żywności}

Pytanie brzmi, czy istnieją instrumenty, inne niż opłaty lub należności i ogólne opodatkowanie, ustanowione przez państwa członkowskie na rzecz finansowania ukż. Wszystko wskazuje na to, że tak. Jednak instrumentami tymi są przede wszystkim inne opłaty i należności.

Orzecznictwo Trybunału Sprawiedliwości wyraźnie podkreśla różnice pomiędzy opłatami i należnościami mającymi na celu pokrycie kosztów poniesionych w ramach ukż, od innych opłat i należności, które również służą jej finansowaniu, ale nie wypełniają pierwszego założenia. W wyroku z 26 lipca 2017 r., w sprawie C-519/16 $6^{13}$, TS podkreślit, że art. 26 i 27 rozporządzenia nr 882/2004 należy interpretować w ten sposób, że nie stoją one na przeszkodzie nałożeniu opłaty, z której przychody nie służą konkretnie finansowaniu kontroli urzędowych, które zostały wywołane przez zobowiązanych do zapłaty tej opłaty lub są wykonywane z korzyścią dla nich. Innymi słowy - w ramach swobody w wyborze instrumentów dotyczących finansowania ukż, określonej w art. 26, państwa członkowskie mogą ustanowić należności inne niż te określone w art. 27 rozporządzenia nr 882/2004 (nieprzeznaczone na pokrycie kosztów w ramach kontroli urzędowych).

Z powyższego orzeczenia TS można wyinterpretować przesłanki odróżniające należność ustanowioną na podstawie art. 27 rozporządzenia nr 882/2004 od innej, ustanowionej na podstawie zasady ogólnej z art. 26. Są to: zdarzenie inicjujące obowiązek uiszczenia opłaty, cel opłaty, przeznaczenie wpływów z tej opłaty, a także istnienie bądź nieistnienie związku między opłatą a wydatkami (kosztami) organu ukż $\dot{z}^{14}$.

${ }_{12}$ Zob. BLL, Revision of Regulation (EC) No. 882/2004 (Officials Control Regulation) (Draft of 6.5.13, COM (2013) 265 final), EFLA, Workshop on the revision...

13 Wyrok Trybunału Sprawiedliwości z 26 lipca 2017 r., C-519/16, Superfoz - Supermercados Lda przeciwko Fazenda Pública, ECLI:EU:C:2017:601.

14 Zob. A. Serlikowska, Glosa do wyroku TS z dnia 26 lipca 2017 r. - Możliwość ustanowienia przez państwo czlonkowskie opłaty pozbawionej celu pokrycia kosztów poniesionych $w$ ramach kontroli urzędowych, „Europejski Przegląd Sądowy” 2018, nr 8, s. 33-37. 
Zatem by uniknąć wątpliwości w zakresie stosowanych przez państwa członkowskie instrumentów, powinno mówić się o „opłatach lub należnościach mających na celu pokrycie kosztów poniesionych w ramach kontroli urzędowych" (art. 27 rozporządzenia nr 882/2004) ${ }^{15}$ oraz opłatach służących ogólnemu finansowaniu ukż (art. 26). Rozporządzenie nr 2017/625 nie eliminuje opisanego dualizmu, nadal dopuszczając ogólne finansowanie (art. 78) oraz szczegółowe opłaty i należności ${ }^{16}$.

Omawiany cel ,pokrycia kosztów poniesionych w ramach kontroli urzędowych" zgodnie z orzecznictwem TS powinien być interpretowany wąsko. Jego realizacja ma miejsce tylko w przypadku, gdy przychody z danej należności służą konkretnie finansowaniu kontroli urzędowych wywołanych przez zobowiązanych do zapłaty lub wykonywanych z korzyścią dla nich ${ }^{17}$. Tak ujęta wykładnia art. 27 zakłada istnienie związku przyczynowego pomiędzy opłatą a realizacją przychodów z niej pochodzących. W tym kontekście pokrycie kosztów poniesionych w ramach ukż może mieć charakter zarówno następczy (opłacane są po czynności wywołanej przez zobowiązanego), jak i uprzedni (opłacane są przed taką czynnością). Co do następczego ponoszenia kosztów zastanawia, jak zbadać dalsze przeznaczenie takiej kwoty, gdy większość państw członkowskich inkorporuje te kwoty do budżetu państwa ${ }^{18}$.

Ponadto zastanawiające jest sformułowanie TS, że przychody z opłaty w rozumieniu art. 27 rozporządzenia nr 882/2004 mogą służyć finansowaniu kontroli urzędowych ,wykonywanych z korzyścią dla zobowiązanych z tytułu

${ }^{15} \mathrm{~W}$ art. 27 ust. 4 rozporządzenia nr 882/2004, prawodawca użył jeszcze sformułowania „opłaty pobrane do celów kontroli urzędowych”, jednak nie oddaje ono istoty tych opłat, podkreślanej w orzecznictwie TS.

16 W zależności od przepisu prawodawca odwołuje się do „opłat lub należności za kontrole urzędowe” (art. 79 ust. 1 rozporządzenia 2017/625), ,opłat lub należności w celu odzyskania (ponoszonych przez właściwe organy) kosztów” (art. 79 ust. 2), czy wreszcie „opłat lub należności w celu pokrycia kosztów kontroli urzędowych i innych czynności urzędowych” (art. 80). Typy opłat lub należności podlegających regulacjom rozdziału VI dotyczącego finansowania ukż są zatem określone przez prawodawcę unijnego w rozporządzeniu nr 2017/625 szerzej niż w rozporządzeniu nr 882/2004. Jednocześnie jednak wciąż dopuszczalne będzie ustanawianie zarówno instrumentów służących ogólnemu finansowaniu jak i opłat lub należności mających na celu pokrycie kosztów ukż.

${ }_{17}$ Zob. wyrok Trybunału Sprawiedliwości z 26 lipca 2017 r., C-519/16.

18 Zob. Food Chain Evaluation Consortium (FCEC) European Commission Directorate General for Health and Consumers, Study on fees or charges collected by the Member States to cover the costs occasioned by official controls, Final Report Part One: Main Study and Conclusions, Bruksela 2009, online: http://www.ceasc.com/Images/Content/2386\%20final\%20report.pdf, [dostęp: 27.08.2018], s. 18-19 i 30-31, Post Consultation Update - March 2014, Proposal for a new Regulation of the European Parliament and of the Council on official controls and other official activities performed to ensure the application of food and feed law, rules on animal health and welfare, plant health, plant reproductive material, plant protection products to replace Regulation (EC) No 882/2004, s. 3. 
tej opłaty". Przedmiotową przesłankę należy interpretować w kontekście przejrzystości opłat i innych należności. W orzeczeniu TS w sprawie C-270 $/ 07^{19}$ zwrócił uwagę, że regulacje dotyczące kontroli urzędowych przyjęto, aby walczyć z zakłóceniami konkurencji. Normy te mają odnosić się do różnych elementów branych pod uwagę przy ustalaniu opłat przeznaczonych na pokrycie kosztów kontroli urzędowych. W opinii TS przejrzystość takich instrumentów polega na skonstruowaniu ich w sposób umożliwiający ponoszącemu opłatę poznanie jej struktury oraz składników w sposób jasny i szczegółowy. Celem takiej regulacji jest możliwość porównania przez tego „dłużnika” jego składających się na opłatę kosztów z kosztami podnoszonymi przez inne podmioty gospodarcze oraz dokonania optymalizacji funkcjonowania swojej działalności z zamiarem ich zaoszczędzenia ${ }^{20}$. Innymi słowy, należność ma w pewien sposób motywować podmioty, na które została nałożona, do przestrzegania przez nie standardów w zakresie żywności tak, by mogły one optymalizować swoją aktywność w łańcuchu rolno-spożywczym i - przez przestrzeganie norm prawa żywnościowego - zmniejszyć koszty przeprowadzanych u nich kontroli.

\section{Zasady ustanawiania opłat i należności mających na celu pokrycie kosztów poniesionych w ramach urzędowej kontroli żywności}

Opisana wyżej przejrzystość opłat lub należności mających na celu pokrycie kosztów poniesionych $\mathrm{w}$ ramach ukż to jedna $\mathrm{z}$ dyrektyw postępowania, jakimi powinny kierować się państwa członkowskie w procesie ustanawiania tych instrumentów. Możliwość optymalizowania kosztów składających się na wymiar opłaty to nie jedyny jej aspekt. Art. 27 ust. 12 rozporządzenia nr 882/2004 nakłada na państwa członkowskie obowiązek podawania do publicznej wiadomości oraz do wiadomości Komisji Europejskiej metod obliczania opłat. W wyniku reformy ukż, do rozdziału VI rozporządzenia nr 2017/625 dotyczącego jej finansowania, wprowadzono art. 85 zatytułowany „Przejrzystość”. Przepis ten będzie wymagał od państw członkowskich, aby zapewniały wysoki poziom przejrzystości w odniesieniu do: 1) metod i danych wykorzystanych do ustalenia wysokości opłat lub należności, 2) kwot stosowanych w odniesieniu do każdej kategorii podmiotów i do każdej kategorii kontroli urzędowych lub innych czynności

19 Wyrok Trybunału Sprawiedliwości z 19 marca 2009 r., C-270/07, Komisja Wspólnot Europejskich przeciwko Republice Federalnej Niemiec, ECLI:EU:C:2009:168. Sprawa dotyczyła dyrektywy poprzedzającej rozporządzenie nr 882/2004. Trybunał orzekał jednak już w momencie obowiązywania rozporządzenia.

${ }^{20}$ Ibidem. 
urzędowych, 3) zestawienia kosztów wynikających z kontroli urzędowych oraz 4) organów lub jednostek odpowiedzialnych za pobieranie opłat lub należności.

Przejrzystość to nie jedyna dyrektywa nakładana przez prawodawcę unijnego na państwa członkowskie w przypadku wyboru przez nie ścieżki finansowania ukż w drodze ustanawiania należności mających na celu pokrycie kosztów poniesionych w ramach ukż. Art. 27 rozporządzenia nr 882/2004 zawiera regulacje o charakterze generalnym, które można określić mianem zasad ${ }^{21}$. Co więcej, sam prawodawca do omawianego już art. 26 dodał tytuł ,zasada ogólna”, niejako prowokując do odszukania pozostałych dyrektyw dotyczących tej kwestii.

Wydaje się, że warto w tym kontekście wyróżnić zasadę nagradzania podmiotów za zachowanie zgodne z prawem żywnościowym. W art. 27 ust. 6 rozporządzenia nr 882/2004 prawodawca nie tyle wskazał, co założył, że w świetle poziomu zgodności wykazanego $\mathrm{w}$ trakcie kontroli urzędowych u danych podmiotów, dalsze kontrole są przeprowadzane u nich ze zmniejszoną częstotliwością. W dodatku państwa członkowskie mogą w takim przypadku ustalić opłatę w zakresie ukż poniżej stawek minimalnych określonych rozporządzeniem ${ }^{22}$. Kwestia ta akcentowana jest wyraźnie w preambule do nowego rozporządzenia dotyczącego ukż (2017/625). Zgodnie z motywem 66 opłaty i należności należy obliczać w sposób nagradzający podmioty ze stałą pozytywną historią zgodności z prawodawstwem Unii dotyczącym łańcucha rolno-spożywczego. $\mathrm{W}$ art. 79 ust. 3 lit. d wskazano natomiast kategorie należności, których kwota może zostać przez państwa członkowskie w obiektywny i niedyskryminacyjny sposób zmniejszona w oparciu o kryterium historii zgodności potwierdzonej kontrolami urzędowymi.

Uwagę zwraca również dyrektywa wskazana w art. 27 ust. 4 lit. a rozporządzenia nr 882/2004, zgodnie z którą pobrane do celów ukż należności nie są wyższe od kosztów poniesionych przez odpowiedzialne właściwe organy ${ }^{23}$. Kwestię tę doprecyzowano w art. 82 rozporządzenia nr 2017/625. Wskazano, że w przypadku obliczeń na podstawie faktycznych kosztów poszczególnych kontroli urzędowych opłaty lub należności nie mogą przekraczać faktycznych kosztów takiej jednostkowej kontroli. Natomiast w sytuacji stosowania staw-

${ }^{21}$ Zob. M. Kordela, Zasady prawa. Studium teoretycznoprawne, Poznań 2012. S. Wronkowska, M. Zieliński, Z. Ziembiński, Zasady prawa. Zagadnienia podstawowe, Warszawa 1974, K. Opałek, J. Wróblewski, Zagadnienia teorii prawa, Warszawa 1969, s. 92, P. Przybysz, Kodeks postępowania administracyjnego. Komentarz, wyd. XII, Warszawa 2017 , s. 44-45, L. Leszczyński, G. Maroń, Pojęcie i treść zasad prawa oraz generalnych klauzul odsyłajacych. Uwagi porównawcze, „Annales Universitatis Mariae Curie-Skłodowska Lublin” 2013, nr 1, s. 81-82.

${ }^{22}$ Por. art. 27 ust. 6 rozporządzenia $n r$ 882/2004.

${ }^{23}$ Jednocześnie zauważyć należy, że prawodawca dopuścił również ustalanie opłat według stawki ryczałtowej lub stawki określonej w rozporządzeniu - zob. art. 27 ust. 4 lit. b rozporządzenia nr 882/2004. 
ki ryczałtowej nie mogą one przekraczać całkowitych kosztów poniesionych w związku z kontrolami przeprowadzanymi w danym okresie referencyjnym. Biorąc pod uwagę powyższe, wydaje się, że można sformułować zasadę adekwatności sprowadzającą się do stwierdzenia, że opłaty lub należności muszą odpowiadać kosztom poniesionym przez organy ukż w ramach dokonanych przez nie względem podmiotu obciążanego czynności.

Zauważyć należy również zasadę bezzwrotności należności, wyrażoną w art. 27 ust. 9 rozporządzenia $\mathrm{nr} 882 / 2004$, a już wkrótce przez art. 82 ust. 2 rozporządzenia $\mathrm{nr} 2017 / 625$. Zgodnie z tymi przepisami opłaty nie powinny być bezpośrednio lub pośrednio zwracane, chyba że zostały pobrane nienależnie. Nie ulega również wątpliwości, że w kontekście finansowania ukż szczególne znaczenie ma jedna $\mathrm{z}$ podstawowych zasad ukż, tj. zasada proporcjonalności. Opłaty i należności powinny być zatem powiązane z wykryciem naruszenia oraz jego charakterem.

\section{Finansowanie urzędowej kontroli żywności w praktyce państw członkowskich}

Trzy lata po wejściu w życie rozporządzenia nr 882/2004 na zlecenie Komisji Europejskiej przeprowadzono badania mające na celu sprawdzenie, jak funkcjonuje mechanizm ustalania opłat i należności w celu pokrycia kosztów poniesionych w ramach ukż ${ }^{24}$. Wykazały one, że na 27 państw członkowskich ${ }^{25}$ w przypadku czternastu (w tym Włoch, Słowacji i Wielkiej Brytanii) nie pokrywają one kosztów ukż, w sześciu państwach (w tym Francji i Niemczech) - jest to możliwe w zakresie niektórych czynności kontrolnych bądź w danych regionach objętych kontrolą, natomiast w siedmiu (w tym Polski), wystarczają one na pokrycie kosztów ukżं .

Ponadto według tych samych badań pobrane na skutek tych instrumentów kwoty inkorporowane były do budżetów państw członkowskich - w całości w przypadku jedenastu krajów (w tym Francji i Słowacji), a w części w przypadku siedmiu krajów (w tym Niemiec, Włoch, Polski), wobec czego nie jest możliwe realne stwierdzenie na co następnie kwoty te zostaną przeznaczone. Jedynie 9 państw członkowskich wyodrębniało tak uzyskane pieniądze na specjalne rachunki i przeznaczało je na pokrycie kosztów ukż ${ }^{27}$.

\footnotetext{
${ }^{24}$ Por. art. 65 rozporządzenia nr 882/2004, FCEC, Study on fees or charges..., s. 1.

${ }^{25}$ Chorwacja weszła do UE 4 lata po sporządzeniu raportu.

${ }^{26}$ Należy mieć na uwadze, że badania w dużej mierze oparto na metodzie ankietowej.

${ }^{27}$ FCEC, Study on fees or charges..., s. 19.
} 
W raporcie podsumowującym powyższe analizy zwrócono uwagę na niejasność opłat i należności oraz okoliczność, że kwoty opłat nie pokrywają rzeczywistych kosztów kontroli ${ }^{28}$. Ponadto podniesiono, że w przeciwieństwie do oczekiwań prawodawcy unijnego wyrażonych w rozporządzeniu nr 882/2004, w większości państw członkowskich w sprawy dotyczące ukż zaangażowanych zostało więcej organów niż jeden, a sam system postrzegany jest jako mocno zdecentralizowany ${ }^{29}$.

W Polsce opłaty i - trzymając się nomenklatury prawa krajowego - inne należności nakładane są przez pięć organów ukż: Inspekcję Weterynaryjną, Inspekcję Sanitarną, Inspekcję Handlową, Inspekcję Jakości Handlowej Artykułów Rolno-Spożywczych oraz Państwową Inspekcję Ochrony Roślin i Nasiennictwa $^{30}$. W piętnastu aktach regulujących zakres działania tych organów, znalazło się około 40 różnych instrumentów finansowych nakładanych na podmioty prowadzące przedsiębiorstwa spożywcze lub działające na rynku pasz. Wśród instrumentów tych trudno znaleźć takie, które są całościowo uregulowane. Brakuje określenia trybu, w jakim powinny być nakładane ${ }^{31}$, terminu zapłaty ${ }^{32}$ czy też stawek kwotowych bądź sposobu ich wyliczania ${ }^{33}$. Wątpliwości budzi również kwestia kwalifikacji, które z instrumentów mają na celu pokrycie kosztów poniesionych $\mathrm{w}$ ramach ukż i podlegają zasadom określonym $\mathrm{w}$ art. 27 rozporządzenia nr 882/2004, a które jedynie regulacjom krajowym. Wszystkie stanowią dochód budżetu państwa, jednocześnie jedynie część z nich, dotycząca przede wszystkim wykrytych w toku kontroli nieprawidłowości ${ }^{34}$, posiada walor

${ }^{28}$ GHK ADAS, Preparatory work to support the impact assessment on reviewing the rules on the financing of official controls, A final report to DG SANCO, Bruksela 2011, s. 13, online: https://ec.europa.eu/food/sites/food/files/safety/official_controls/docs/ghk_study_en.pdf [dostęp: 28.08.2018].

${ }^{29}$ FCEC, Study on fees or charges...s. E2.

${ }^{30}$ Zob. P. Wojciechowski, Organy urzędowej kontroli żywności w Polsce, „Kontrola Państwowa" 2014, nr 1, s. 49-65.

${ }^{31}$ Zob. art. 30 ust. 1 ustawy z dnia 29 stycznia 2004 r. o Inspekcji Weterynaryjnej (t.j. Dz.U. z 2018 r. poz. 1557), Wyrok WSA we Wrocławiu z dnia 23 lutego 2012 r., sygn. akt II SA/Wr 838/11, CBOSA, dotyczący ustalania wysokości opłaty za nadzór nad ubojem zwierząt rzeźnych.

32 Zob. opłata za przeprowadzenie granicznej kontroli fitosanitarne $\mathrm{z}$ art. 32 ustawy z dnia 18 grudnia 2003 r. o ochronie roślin (t.j. Dz.U. z 2017 r., poz. 2138 ze zm.).

${ }^{33}$ Zob. należność pieniężna stanowiąca zwrot kosztów dokumentacji, badań lub dowodów naukowych niezbędnych do przygotowania wstępnego sprawozdania odnośnie do nowej żywności wprowadzanej do obrotu w zakresie określonym przepisami rozporządzenia nr 258/97 z art. 92 ust. 3 ustawy z dnia 25 sierpnia 2006 r. o bezpieczeństwie żywności i żywienia (t.j. Dz.U. z 2018 r., poz. 1541 ze zm.).

${ }^{34}$ Zob. opłata za czynności przeprowadzone w ramach kontroli, jeżeli stwierdzono, że artykuły rolno-spożywcze nie odpowiadają wymaganiom w zakresie jakości handlowej z art. 39 ustawy z dnia 21 grudnia 2000 r. o jakości handlowej artykułów rolno-spożywczych (t.j. Dz.U. z 2018 r., poz. 2164 ze zm.). 
„przejrzystości” i zapewnia możliwość ewentualnej optymalizacji ponoszonych z tego tytułu kosztów przez kontrolowanych.

Jak wskazała Niemiecka Federacja Prawa Żywnościowego i Nauk Żywnościowych ${ }^{35}$, zgodnie z zasadami pomocniczości i proporcjonalności, za konieczne należy uznać ustandaryzowanie regulacji dotyczących finansowania ukż na poziomie UE tak, by zagwarantować wysoką jakość tych kontroli. Jednak sposób tego finansowania musi jednocześnie uwzględniać sytuację i strukturę organów ukż w poszczególnych państwach członkowskich ${ }^{36}$.

Nie sposób nie zauważyć, że struktura organów ma wpływ na koszty ponoszone przez organy ukż w poszczególnych państwach członkowskich. Trudno wyobrazić sobie regulację, która jest w stanie uwzględnić znaczne różnice związane z kosztami funkcjonowania ukż w różnych krajach, chociażby w zakresie wynagrodzeń ich pracowników. Różnice wydają się zbyt wielkie. Przykładowo, w niektórych państwach członkowskich (Holandia, Francja, UK) podjęto decyzję o finansowej racjonalizacji służb weterynaryjnych. Polega ona na korzystaniu przez państwo z usług weterynarzy na kontraktach, którzy przeprowadzają kontrole żywności w ramach swojej dodatkowej działalności i nie są zatrudnieni jako urzędnicy państwowi, członkowie służby cywilnej ${ }^{37}$. W ten sposób państwo oszczędza na kosztach zatrudnienia, a otrzymaną kwotę przeznacza na kolejne kontrole. Jednocześnie zauważyć należy, że w Polsce wynagrodzenie pracowników organów ukż, nawet na etatach, oceniane jest jako niewystarczające do wykonywania ich zadań ${ }^{38}$.

Problematyczna jest również kwestia obliczania należności tak, by nie były one wyższe od kosztów poniesionych przez właściwe organy w ramach konkretnych działań kontrolnych. Zauważyć należy, że precyzyjność określonych rozporządzeniami nr 882/2004 i 2017/625 wyliczeń jest jedynie pozorna. Umowność przedmiotowych norm podkreślał już wielokrotnie Trybunał Sprawiedliwości, powielając opinię ugruntowaną jeszcze na gruncie dyrektywy Rady nr 85/73/EWG, poprzedzającej rozporządzenie nr 882/2004, że z natury opłaty ryczałtowej wynika, że raz przekracza ona aktualny koszt działań, które ma finansować, innym razem jest natomiast niższa niż rzeczywiste koszty ${ }^{39}$.

${ }^{35}$ Bund für Lebensmittelrecht und Lebensmittelkunde e. V. (BLL)

${ }^{36}$ Por. BLL, Revision of Regulation (EC) No. 882/2004 (Officials Control Regulation) (Draft of 6.5.13, COM (2013) 265 final).

${ }^{37}$ Por. FCEC, Study on fees or charges..., s. E2 i 12.

${ }^{38}$ Por. Opinia Krajowej Rady Lekarsko-Weterynaryjnej do projektu ustawy o zmianie ustawy o Inspekcji Weterynaryjnej, sierpień 2008 r., P. Szewioła, Nie będzie komu walczyć z pomorem. Weterynarze odejda, jeśli nie dostana podwyżek, „Gazeta Prawna” 21.02.2018 r.

${ }_{39}$ Por. wyrok Trybunału Sprawiedliwości z 30 maja 2002 r., sprawy połączone C-284/00 i C-288/00, Stratmann GmbH und Co. KG and Landrätin des Kreises Wesel (C-284/00), and between Fleischversorgung Neuss GmbH und Co. KG and Landrat des Kreises Neuss (C-288/00), 
Obliczenia dotyczące faktycznych kosztów poszczególnych kontroli również noszą znamiona pewnej pozorności, ponieważ w praktyce obliczanie np. kosztów tuszu do drukarki zużytego na potrzeby wydruku konkretnego protokołu kontroli, paliwa za dojazd na miejsce kontroli czy wynagrodzeń pracowników, którzy jednego dnia mogą rozpocząć i kontynuować kilka kontroli u różnych podmiotów, musi podlegać pewnym zaokrągleniom i uogólnieniom ${ }^{40}$. Nie ulega jednak wątpliwości, że im precyzyjniejsze wyliczenia, tym większe zaufanie podmiotów obciążanych tymi instrumentami do organów je nakładających.

\section{Podsumowanie}

Prawodawca unijny zarówno w rozporządzeniu nr 882/2004, jak i rozporządzeniu nr 2017/625 nie zdefiniował podstawowych pojęć związanych z tą problematyką. Ukształtował normy w sposób bardzo ogólny i pozostawił państwom członkowskim znaczny margines swobody. Swoboda ta nie została wykorzystana przez poszczególnych prawodawców krajowych właściwie. W rezultacie przepisy wprowadzone po to, by zapewnić urzędowej kontroli żywności odpowiednie finansowanie nie wypełniły swojego podstawowego celu. Opłaty i należności ustanowione przez państwa członkowskie w większości przypadków nie pokrywają kosztów poniesionych w ramach urzędowych kontroli.

Podkreślić należy newralgiczność regulowania kwestii finansowych w unijnych rozporządzeniach. W istocie można postrzegać to jako ingerencję prawodawcy unijnego w budżety państw członkowskich, na które UE co do zasady nie ma wpływu. ${ }^{41}$. Tym samym pozostawienia znacznej swobody w kształtowaniu norm dotyczących finansowania urzędowej kontroli żywności nie można oceniać negatywnie. Bez wątpienia krytycznie ocenić można natomiast działalność prawotwórczą państw członkowskich w zakresie, w którym nie zrealizowała ona celu unijnej regulacji.

Oparcie systemu ${ }^{42}$ finansowania ukż na instrumentach niejasnych, budzących wątpliwości i kształtowanych w sposób dowolny wpływa na obniżenia zaufania podmiotów do organów przeprowadzających kontrolę. Zachęca również do

ECLI:EU:C:2002:315, pkt 52, a także wyrok Trybunału Sprawiedliwości z dnia 19 marca 2009 r., C-270/07, Wyrok Trybunały Sprawiedliwości z dnia 7 lipca 2011 r., C-523/09.

${ }^{40}$ Por. art. 81 lit. a i c rozporządzenia nr 2017/625.

${ }^{41}$ Poza kompetencjami wyłącznymi w zakresie polityki pieniężnej dla krajów strefy euro por. podział kompetencji w UE, online: https://eur-lex.europa.eu/legal-content/PL/TXT/?uri=LEGISSUM\%3Aai0020 [dostęp: 29.05.2018].

${ }^{42}$ Pojęcie systemu w odniesieniu do finansowania urzędowej kontroli żywności czy opłat i należności jest stosowane umownie na potrzeby wyodrębnienia pewnej grupy norm. Nie przesądza zaś o charakterze systemowym łączących je relacji. 
zachowań zmierzających do uniknięcia konsekwencji wynikających z takich kontroli $^{43}$. W rezultacie prowadzi do przesunięcia zasadniczego celu urzędowej kontroli żywności z ochrony dóbr, na których powinno zależeć wszystkim podmiotom, na unikanie nadmiernych obciążeń ze strony państwa.

\section{FROM THE LEGAL ISSUES OF FINANCING OFFICIAL CONTROLS OF FOODSTUFFS}

\section{Summary}

The purpose of these deliberations is an attempt to answer the question of whether the legal instruments concerning the financing of statutory food controls ensure proper functioning of this form of supervision. In particular, the functioning of the system of fees in various EU Member States has been analysed. It has been found out that despite the fact that the EU legislator has regulated the system of financing official controls of foodstuffs, most national regulations do not provide sufficiently for the proper functioning of the control system, and do not ensure that all costs incurred are recovered. Moreover, the unclear criteria according to which the financing system operates reduces confidence in public administration bodies.

\section{SULLE QUESTIONI GIURIDICHE LEGATE AL FINANZIAMENTO DEL CONTROLLO UFFICIALE DEGLI ALIMENTI}

\section{Riassunto}

L'obiettivo delle considerazioni è di rispondere alla domanda se gli strumenti giuridici relativi al finanziamento del controllo ufficiale degli alimenti svolto da parte degli organi dello Stato riescano a garantire il suo corretto svolgimento. L'autrice ha fornito una descrizione generale del funzionamento del sistema di pagamenti in vari Stati membri dell'UE. Nella parte conclusiva, ha affermato che, benché il legislatore dell'UE abbia disciplinato il sistema di finanziamento dei controlli ufficiale degli alimenti nazionali, nella maggior parte dei casi le regolazioni non garantiscono la copertura di tutti i costi delle attività di controllo svolte. Inoltre, il loro finanziamento in base a criteri vaghi porta ad abbassare il livello di fiducia nelle amministrazioni pubbliche.

${ }^{43}$ Co nie jest tożsame z przestrzeganiem przepisów prawa żywnościowego. 